\title{
PENGARUH LINGKUNGAN KELUARGA TERHADAP MINAT BERWIRAUSAHA PESERTA DIDIK SMK DI KABUPATEN SUBANG
}

\author{
Anita Wiani, Eeng Ahman, Amir Machmud \\ Email: anitawiani@gmail.com; eengahman@yahoo.co.id; amir@upi.edu
}

\begin{abstract}
ABSTRAK
Kemunculan sebuah organisasi usaha baru disebabkan oleh faktor sumber daya manusia dan keputusan untuk berwirausaha ditentukan oleh faktor lingkungan yang mempengaruhi seseorang untuk menjadi wirausaha. Minat peserta didik untuk berwirausaha masih rendah sehingga masih perlu penelitian yang lebih lanjut guna meningkatkan minat peserta didik khususnya di Sekolah Menengah Kejuruan (SMK) untuk dapat menjadi wirausaha. Hal tesebut diperlukan guna untuk meningkatkan jumlah wirausaha sebagai salah satu penentu perkembangan suatu daerah maupun Negara. Adapun tujuan dari penelitian ini yaitu untuk mengetahui hubungan antara lingkungan keluarga dengan minat berwirausaha peserta didik SMK di Kabupaten Subang. Metode yang digunakan dalam penelitian ini yaitu survey dimana teknik pengolahan dan analisis data dalam penelitian ini menggunakan angket, wawancara, dan observasi langsung. Lingkungan keluarga dalam penelitian ini memiliki pengaruh yang signifikan terhadap minat berwirausaha peserta didik SMK di Kabupaten Subang dengan skor $0.000-0.043$. Penelitian ini memiliki reliabilitas yang tinggi dengan skor mencapai 0.703 .
\end{abstract}

Kata Kunci: Minat Berwirausaha, Lingkungan Keluarga, Pesert didik SMK

\section{A. LATAR BELAKANG PEELITIAN}

Berdasarkan data Global Enterpreneur Indeks (GEI) tahun 2015 Negara yang maju baik dari sektor ekonomi dan industri ditunjukkan dengan indeks pertumbuhan entrepreneurship, sedangkan menurut data dari GEI Indonesia menempati posisi 120 dari 130 dengan skor 21,0 menempati posisi 10 terendah sehingga perlu kesadaran penduduk Indonesia untuk dapat memiliki jiwa wirausaha dan melahirkan usaha baru (Mandiri, Dan, Lestari, Hasiolan, \& Minarsih, 2016). Jumlah lulusan dari berbagai bidang ilmu dari tahun ke tahun semakin bertambah, di satu sisi kondisi ini tidak diimbangi dengan jumlah penyerapan tenaga kerja baik di dunia industri maupun di pemerintahan, sehingga menyebabkan jumlah angka pengangguran tinggi (Kusumawati, 2016). Urutan kewirausahaan Indonesia berdasarkan data yang diperoleh dari Global Entrepreneurship Monitor (GEM) Tahun 2015-1016 Indonesia masih rendah jika dibandingkan dengan Negara lain khususnya diantara anggota ASIA lainnya.

Tabel 1

Urutan Kewirausahaan per Daerah dan

Persentase Penduduk Berdasarkan Usia 18-64 Tahun

\begin{tabular}{llccccccc}
\hline & & Region & Economy & $\begin{array}{l}\text { Entrepreneurship } \\
\text { as a Good Career } \\
\text { Choice }\end{array}$ & $\begin{array}{l}\text { High } \\
\text { to Successful } \\
\text { Enrepreneurs }\end{array}$ & $\begin{array}{l}\text { Media } \\
\text { for } \\
\text { Entrepreneurship }\end{array}$ \\
\hline $\begin{array}{l}\text { Asia \& } \\
\text { Oceana }\end{array}$ & Australia & 36 & 56.4 & 21 & 70.1 & 10 & 72.3 \\
& China & 22 & 65.9 & & & & & \\
& India & $50 \mathrm{~T}$ & 39.3 & 53 & 77.6 & 6 & 77.2 \\
& Indonesia & 6 & 74.4 & 7 & 46.6 & 52 & 39.4 \\
& Iran & 37 & 56.3 & 5 & 81.4 & 4 & 79.4 \\
\hline & Israel & 23 & 64.5 & 1 & 82.3 & 35 & 58.3 \\
\hline & Kazakhstan & 4 & 76.9 & 3 & 86.2 & 37 & 54.8 \\
\hline
\end{tabular}




\begin{tabular}{lcccccc}
\hline & & & & & \\
\hline Korea & 52 & 38.0 & 47 & 53.5 & 26 & 61.5 \\
\hline Malaysia & $50 \mathrm{~T}$ & 39.3 & 50 & 51.0 & 24 & 63.9 \\
\hline Philipines & 5 & 74.6 & 14 & 76.2 & 2 & 81.5 \\
\hline Taiwan & 7 & 74.0 & 39 & 62.7 & 1 & 85.6 \\
Thailand & 15 & 71.5 & 27 & 69.4 & 9 & 72.5 \\
Vietnam & 11 & 73.3 & 16 & 75.8 & 8 & 73.5 \\
\hline Total & & 61.9 & & 70.5 & & 69.2 \\
\hline
\end{tabular}

Sumber: Global Entrepreneurship Monitor (GEM) Tahun 2015-1016

Berdasarkan tabel tersebut dapat kita lihat bahwa pemilihan karir sebagai wirausaha dari penduduk Indonesia yang berusia 18 sampai 64 tahun masih rendah yaitu sebanyak 7 persen, sedangkan Malaysia jauh lebih besar yaitu mencapai 50 persen. Pada penelitian yang dilakukan sebelumnya oleh Resti Elfia Shanti yang mengacu pada data Badan Pusat Statistik tentang data penduduk Indonesia yang berusia 15 tahun keatas menurut status pekerjaan utama periode agustus 2013 - agustus 2015 menyatakan bahwa sebanyak 18,15 persen bekerja sebagai wirausaha, angka tersebut jauh lebih sedikit dibandingkan dengan jumlah buruh/ karyawan sebanyak 46,24 persen.

Tabel 2

Data Pencari Kerja Berdasarkan Jenjang Pendidikan Tahun 2017

\begin{tabular}{ccccccc}
\hline Jenjang & Januari & Februari & Maret & April & Mei & Juni \\
\hline SMK & $41.21 \%$ & $27.70 \%$ & $33.97 \%$ & $62.67 \%$ & $60.14 \%$ & $50.57 \%$ \\
SMA & $37.17 \%$ & $56.75 \%$ & $37.97 \%$ & $17.52 \%$ & $30.36 \%$ & $39.96 \%$ \\
\hline Lain-Lain & $21.62 \%$ & $15.55 \%$ & $28.06 \%$ & $19.81 \%$ & $9.50 \%$ & $9.47 \%$ \\
\hline
\end{tabular}

Sumber: Dinas Tenaga Kerja dan Transmigrasi Kabupaten Subang (Data diolah)

Berdasarkan data dalam tabel tersebut di atas dapat diketahui bahwa para pencari kerja di Kabupaten Subang sebagian besar berasal dari lulusan SMK. Begitu banyaknya para pencari kerja lulusan SMK tidak dapat sepenuhnya terserap oleh Dunia Usaha/ Dunia Industri (DU/DI).

Peneliti melakukan pra penelitian di SMK PGRI Subang dengan sampel sebanyak 329 peserta didik dari 7 kompetensi keahlian, yaitu: jurusan Pemasaran, Administrasi Perkantoran, Akuntansi, Busana Butik, Teknis Bisnis Sepeda Motor, Teknik Komputer Jaringan, Akomodasi Perhotelan, dimana hasil pada survei tersebut menunjukkan masih kurangnya minat berwirausaha pada peserta didik di SMK PGRI Subang. Jika kondisi tersebut terus berlangsung maka dapat memberikan dampak buruk pada perekonomian di Kabupaten Subang, disamping itu visi dari SMK PGRI Subang pun sulit untuk tercapai, yaitu menjadi sekolah unggulan wirausaha sesuai dengan kompetensi keahlian yang agamis dan berwawasan lingkungan.

Beberapa negara berkembang dimana rendahnya pembangunan di negara tersebut dikaitkan dengan adanya masalah pada usaha baru, dimana lahirnya usaha baru menjadi masalah serius bagi negara tersebut (Leef, 2015). Disisi lain itu minat berwirausaha di Indonesia masih sangat rendah dimana jumlah wirausahawan di Indonesia baru 0,18 persen dari jumlah penduduk, masih jauh di bawah negara lain yaitu dibandingkan dengan Malaysia yang sudah 2 persen, Amerika 4 persen, dan Singapura 7 persen. Suatu negara akan maju dan stabil perekonomiannya jika penduduk yang menjadi wirausahawan minimal 2 persen dari jumlah penduduk (Aprilianty, 2012). Ernanie dalam seminarnya mengungkapkan ada kecenderungan, semakin tinggi tingkat pendidikan maka semakin besar keinginan mendapat pekerjaan yang aman sehingga mereka tidak berani ambil pekerjaan berisiko seperti berwirausaha (Asawi, 2011).

Pembangunan ekonomi suatu daerah atau suatu negara pada dasarnya merupakan interaksi dari berbagai kelompok variabel antara lain sumber daya manusia, sumber daya alam, modal, teknologi dan lain- lain (Kemiskinan, Ekonomi, Belanja, Tahun, \& Mirza, 2012). Kewirausahaan berdampak pada perkembangan suatu negara (Burger-Helmchen, 2012). Salah satu solusi yang ditawarkan pemerintah untuk mengurangi angka pengangguran adalah 
menciptakan lapangan kerja dengan model enterpreneur (Yusanto:2002 dalam (Asawi, 2011). Wirausaha di Indonesia sebaiknya terus ditingkatkan, dengan berwirausaha akan menciptakan lapangan pekerjaan baru dan akan menyerap tenaga kerja, sehingga akan mengurangi pengangguran (Chinmay et al., 2016). Sekolah Menengah Kejuruan (SMK) memiliki peluang yang cukup besar untuk ikut serta dalam membangun sistem perekonomian dengan memanfaatkan tahap perkembangan remaja, mendidik siswa agar berminat untuk berwirausaha (Aprilianty, 2012).

Kemunculan sebuah organisasi usaha baru disebabkan oleh faktor sumber daya manusia (Lichtenstein, Carter, Dooley, \& Gartner, 2007). Keputusan untuk berwirausaha ditentukan oleh faktor lingkungan yang mempengaruhi seorang wirausaha (Fu, 2016). Beberapa tahun terakhir ini banyak ekonom yang menyatakan bahwa jiwa wirausaha berkaitan erat dengan ukuran dari perusahaan itu sendiri (Gicheva \& Link, 2015), sedangkan teknologi baru yang digunakan oleh para wirausaha yang baru lahir merupakan upaya yang dilakukan tidak hanya untuk memperluas usaha tetapi juga untuk memenuhi kebutuhan. (Gicheva \& Link, 2015). Menurut Alam (2010: 12) yang paling mendorong seseorang untuk memasuki karir wirausaha yaitu personal attribute dan personal environment (Aprilianty, 2012).

Kewirausahaan adalah suatu cara berpikir, menelaah, dan bertindak yang didasarkan pada peluang bisnis, pendekatan holistik, dan kepemimpinan yang seimbang (Timmons \& Spinelli, n.d.). Kewirausahaan adalah kemampuan kreatif dan inovatif yang dijadikan dasar, kiat, dan sumber daya untuk mencari peluang menuju sukses (Asawi, 2011). Penelitian terdahulu menyimpulkan bahwa lingkungan keluarga berpengaruh terhadap minat wirausaha dimana minat dapat didefinisikan sebagai sesuatu yang membangkitkan perhatian pada suatu hal dan minat mengindikasikan apa yang diinginkan atau dilakukan orang atau apa yang mereka senangi (Aprilianty, 2012).

Peran keluarga juga sangat penting dalam menumbuhkan minat berwirausaha (Wisnu Septian Ginanjar Prihantoro dan Hadi, 2016). Pendidikan berwirausaha dapat berlangsung sejak usia dini dalam lingkungan keluarga dimana seorang ibu dan ayah yang berwirausaha memberikan inspirasi kepada anak untuk menjadi wirausahawan (Aprilianty, 2012). Dalam penelitian ini kerangka pemikiran teoritisnya menggambarkan tentang pengaruh dari faktor lingkungan keluarga peserta didik terhadap minat berwirausaha. Permasalahan yang dihadapi oleh Negara berkembang khususnya tingkat wirausaha yang masih rendah seperti yang terjadi di Indonesia menyebabkan peneliti tertarik untuk mengangkat hal tersebut dalam penelitian.

\section{B. TINJAUAN PUSTAKA}

1. Wirausaha

Kata wirausaha secara luas muncul setelah keluarnya Instruksi Presiden (Inpres) RI Nomor 4 Tahun 1995 tanggal 30 Juni 1995 tentang gerakan nasional memasyarakatkan dan membudayakan kewirausahaan, dan istilah tersebut merupakan padanan istilah entrepreneur. Entrepreneur diambil dari bahasa Prancis mengandung arti beteen taker atau go-between, jika diterjemahkan ke dalam bahasa Inggris menjadi to undertake (Astamoen, 2008).

Menurut Encyclopedia of Amerika (1984), entrepreneur adalah pengusaha yang memiliki keberanian untuk mengambil resiko dengan menciptakan produksi, termsuk modal, tenaga kerja dan bahan, serta dari usaha bisnis mendapatkan laba. Menurut The American Heritage Dictionary of the English Language, entrepreneur diartikan sebagai "a person who organizes, operates, and assumes the risk for a business venture", dengan kata lain bahwa entrepreneur merupakan orang yang megelola dan mengoperasikan sebuah usaha dan mampu mengelola resiko (Astamoen, 2008).

Lampiran Keputusan Menteri Koperasi dan Pembinaan Pengusaha Kecil Nomor 961/KEP/M/XI/1995 dicantumkan bahwa Wirausaha adalah orang yang mempunyai semangat, sikap, perilaku dan kemampuan kewirausahaan, sedangkan menurut Suryana (dalam Asawi, 2011) seorang wirausaha dapat dideskripsikan; memiliki wawasan komersial dan kesadaran akan 
pasar, memiliki kemauan untuk bekerja tekun dan mandiri, memiliki pikiran yang inovatif dan kreatif, memiliki kemampuan untuk mengelola dan mengarahkan pergaulan, memiliki kemampuan untuk bergaul dengan orang lain dari segala tindakan.

Wirausaha berasal dari kata wira dan usaha, wira mengandung arti manusia yang unggul sedangkan usaha mengandung arti berbuat sesuatu sehingga wirausaha yaitu seseorang yang memiliki keunggulan dalam menjalankan suatu usaha dalam hal ini mengandung pemahaman sesuatu yang bersifat bisnis. Wirausaha adalah seseorang yang mengembangkan produk baru atau ide baru dan membangun bisnis dengan konsep baru, dalam hal ini menuntut sejumlah kreativitas dan sebuah kemampuan untuk melihat trend yang berlaku untuk menjadi seorang wirausaha (Aprilianty, 2012). Menurut Victor Kiam entrepreneur atau wirausaha adalah orang yang mudah menemukan sedikit perbedaan antara rintangan dan kesempatan serta mampu mengambil keuntungan dari kondisi tersebut (MacMillan, 2010).

Menurut Meredith bahwa wirausaha adalah orang-orang yang mempunyai kemampuan melihat dan menilai kesempatan usaha serta mengumpulkan sumber daya yang dibutuhkan guna mengambil keuntungan daripadanya dan mengambil tindakan yang tepat guna memastikn kesuksesan, sedangkan menurut Totok S. Wiryasaputra seorang wirausaha adalah orang yang ingin bebas merdeka mengatur kehidupannya sendiri dan tidak tergantung pada belas kasihan orang lain. Pendapat tersebut sejalan dengan pemahanan yang kemukanan oleh Kao, dimana Kao mendefinisikan wirausaha dengan menekankan pada aspek kebebasan berusaha yang dinyatakan sebagai berikut: "An entrepreneur is and independent, growth oriented owner-operator", dengan demikian seorang wirausaha merupakan orang yang mempunyai kemampuan melihat dan menilai kesempatan bisnis, mengumpulkan sumber daya yang dibutuhkan guna mengambil keuntungan daripadanya dan mengambil tindakan yang tepat guna memastikan kesuksesan (Yuyus Suryana \& Kartib Bayu, 2010).

Teory of Planned Behavior (TPB) menjelaskan bahwa niat seseorang terhadap perilaku dibentuk oleh faktor; sikap attitude toward the behavior, subjective norms, dan perceived behavioral control. TPB sesuai digunakan untuk menjelaskan berbagai perilaku di dalam kewirausahaan. Sebagaimana dikatakan oleh Ajzen (1991) bahwa TPB is suitable to explain any behavior which requires planning, such as entrepreneurship (Budi Wahyono, Siswandari, 2013). Ajzen (Ajzen, 2005) menjelaskan bahwa; (1) sikap terhadap perilaku ditetukan oleh keyakinan mengenai konsekuensi dari suatu perilaku, keyakinan berkaitan dengan penilaian subjektif individu terhadap dunia sekitarnya serta pemahaman individu mengenai diri dan lingkungannya dilakukan dengan cara menghubungkan antara perilaku tertentu dengan berbagai manfaat maupun kerugian yang akan diperoleh jika melakukan atau tidak melakukannya. (2) norma subjektif adalah persepsi individu terhadap harapan dari orang-orang yang berpengaruh dalam kehidupannya mengenai dilakukan atau tidak melakukannya. Norma subjektif pun dipengaruhi oleh keyakinan. (3) kontrol perilaku adalah persepsi individu mengenai mudah atau sulitnya mewujudkan perilaku tertentu, sedangkan kontrol perilaku berkaitan erat dengan konsep efikasi diri yang dikemukakan oleh Bandura dimana efikasi diri adalah keyakinan individu bahwa ia akan berhasil menguasai keterampilan yang dibutuhkan untuk menyelesaikan tugas tertentu (Ramdhani, 2011).

Kewirausahaan adalah suatu cara berfikir, menelaah, dan bertindak yang didasarkan pada peluang bisnis, pendekatan holistik dan kepemimpinan yang seimbang dimana kewirahausahaan menghasilkan kreasi, kemajuan, realisasi dan pembaharuan nilai perusahaan bukan hanya bagi pemiliknya tetapi juga bagi pegawai dan pemegang saham (Timmons \& Spinelli, n.d.). Menurut Miller Kewirausahaan mewakili perilaku organisasi dimana elemen utama kewirausahaan yaitu berani mengambil resiko, proaktif dan melakukan inovasi (Thomson, 2006). Menurut Usman, pengertian wirausahawan dalam konteks manajemen adalah seseorang yang memiliki kemampuan dalam menggunakan sumber daya, seperti finansial, bahan mentah dan tenaga kerja untuk menghasilkan suatu produk baru, bisnis baru, proses produksi ataupun pengembangan organisasi dimana wirausaha adalah seseorang yang memiliki kombinasi unsur-unsur internal 
yang meliputi kombinasi motivasi, visi, komunikasi, optimisme, dorongan semangat dan kemampuan untuk memanfaatkan peluang usaha sehingga dapat disimpulkan bahwa wirausahawan adalah pionir dalam bisnis, inovator, penanggung resiko, yang memiliki visi ke depan dan memiliki keunggulan dalam berprestasi di bidang usaha (Hakim, 2010).

Dalam lampiran Keputusan Menteri Koperasi dan Pembinaan Pengusahan Kecil Nomor 961/KEP/M/XI/1995, dicantumkan bahwa Kewirausahaan adalah semangat, sikap, perilaku dan kemampuan seseorang dalam menangani usaha atau kegiatan yang mengarah pada upaya mencari, menciptakan serta menerapkan cara kerja, teknologi dan produk baru dengan meningkatkan efisiensi dalam rangka memberikan pelayanan yang lebih baik dan atau memperoleh keuntungan yang lebih besar. Kewirausahaan adalah suatu kemampuan dalam menciptakan nilai tambah di pasar melalui proses pengelolaan sumber daya dengan cara-cara baru yang berbeda, melalui; pengembangan teknologi baru, penemuan pengetahuan ilmiah baru, perbaikan produk dan jasa yang ada, penemuan cara-cara baru untuk menghasilkan barang lebih banyak dengan sumber daya yang lebih efisien. (Asawi, 2011).

Tahun 1950-an, pendidikan kewirausahaan mulai dirintis di beberapa negara seperti di Eropa, Amerika dan Canada, sejak tahun 1970-an banyak universitas atau perguruan tinggi yang mengajarkan kewirausahaan "entrepeneurship" atau "small business management" atau "new venture management", pada tahun 1980-an hampir 500 sekolah di Amerika Serikat memberikan pendidikan Kewirausahaan, yang saat itu di Indonesia kewirausahaan dipelajari baru terbatas pada beberapa sekolah atau perguruan tinggi tertentu saja (Hakim, 2010). Pendidikan kewirausahaan telah diajarkan sebagai suatu disiplin ilmu tersendiri yang independen, yang menurut Soeharto Prawirokusumo adalah dikarenakan oleh:

1. Kewirausahaan berisi "body of knowledge" yang utuh dan nyata (distinctive), yaitu ada teori, konsep, dan metode ilmiah yang lengkap.

2. Kewirausahaan memiliki dua konsep, yaitu posisi "venture start up" dan "venture growth". Hal ini jelas tidak masuk dalam "frame work general management courses" yang memisahkan antara "management" dengan "business ownership"

3. Kewirausahaan merupakan disiplin ilmu yang memiliki objek tersendiri, yaitu kemampuan untuk menciptakan sesuatu yang baru dan berbeda. Kewirausahaan merupakan alat untuk menciptakan pemerataan berusaha dan pemerataan pendapatan atau kesejahteraan rakyat yang adil dan makmur.

Proses kewirausahaan adalah kreasi atau penemuan peluang usaha diikuti oleh kemauan dan tindakan meraih peluang. Kewirausahaan klasik menurut Timmons dan Spinelli dalam bukunya yang berjudul New venture creation entrepreneurship for the $21^{\text {st }}$ century adalah perusahaan pemula yang masih mentah dimulai dengan ide usaha yang kemudian berkembang menjadi suatu perusahaan besar. Seorang wirausaha yang sukses memiliki kepemimpian yang kuat dan mampu bekerja sama dalam tim serta mampu menangkap peluang bisnis ditenah-tengah kontradiksi dan kebingungan, selain itu kewirausahaan membutuhkan keterampilan mencari dan mengontrol sumber daya.

Menurut (Suryana, 2006) dalam bukunya Innovation and Entrepreneurship Drucker mengemukakan perkembangan teori kewirausahaan menjadi tiga tahapan: a) Teori yang mengutamakan peluang usaha, teori ini disebut teori ekonomi, yaitu wirausaha akan muncul dan berkembang apabila ada peluang ekonomi; b) Teori yang mengutamakan tanggapan orang terhadap peluang, yakni teori Sosiologi yang mencoba menerangkan mengapa beberapa kelompok sosial menunjukkan tanggapan yang berbeda terhadap peluang usaha dan teori psikologi yang mencoba menjawab karakateristik perorangan yang membedakan wirausaha dan bukan wirausaha serta karakteristik perorangan yang membedakan wirausaha berhasil dan tidak berhasil dan c) Teori yang mengutamakan hubungan antara perilaku wirausaha dengan hasilnya, disebut dengan teori perilaku, yaitu yang mencoba memahami pola perilaku wirausaha (Wibowo, 2011). 
Hisrich \& Peter (2002: 52) menyebutkan bahwa karakteristik wirausaha ada 7 yaitu; seorang wirausaha memiliki kemampuan untuk memahami lingkungan, memiliki visi atau pandangan kedepan dan fleksibel/ tidak kaku, memiliki kreatifitas dalam pengelolaan usaha, dapat bekerja sama dalam tim, terbuka, dapat membangun kerjasama dalam memajukan perusahaan, serta mampu mempertahankan diri (Sukardi, 2013). Ciri-ciri wirausaha menurut Timmons dan Spinelli yaitu; memiliki daya improvisasi, cepat, cerdik, dan mampu menciptakan hal baru (Timmons \& Spinelli, n.d.), sedangkan menurut Thomson bahwa kesuksesan wirausaha yaitu terletak pada terlibatnya peran wirausaha dalam manajerial perusahaan yang sesuai dengan budaya maupun struktur organisasi yang mendukung (Thomson, 2006). Menggambarkan perilaku wirausaha berkaitan erat dengan komitmen yang dimiliki wirausaha itu sendiri dalam menjalankan usahanya (Bill, Bjerke, \& Johansson, 2010).

Bygrave (Yuyus Suryana \& Kartib Bayu, 2010) mengemukakan beberapa karakteristik dari wirausaha yang berhasil memiliki sifat-sifat sebagai berikut:

1. Dream, seorang wirausaha mempunyai visi bagaimana keinginannya terhadap masa depan pribadi dan bisnisnya termasuk kemampuan untuk mewujudkan impiannya.

2. Decisiveness, seorang wirausaha adalah orang yang tidak bekerja lambat, membuat keputusan yang cepat dengan penuh perhitungan dan ini merupakan kunci dalam kesuksesan usahanya.

3. Doers, begitu pelaku mengambil keputusan langsung ditindaklanjuti, dan tidak mau menunda kesempatan yang dapat dimanfaatkan.

4. Determination, bahwa dalam melaksanakan kegiatan penuh saksama, rasa tanggung jawab yang dimiliki tinggi, dan tidak mudah menyerah meski dihadapkan pada berbagai rintangan yang sulit diatasi.

5. Dedication, dedikasinya sangat tinggi, dan terkadang lebih mementingkan bisnisnya daripada keluarganya.

6. Devotion, amat senang dan tergila-gila serta mencintai bisnisnya termasuk produk yang dihasilkannya sehingga menjadi pendorong dalam mencapai keberhasilan yang efektif dalam menjual dan menawarkan produknya.

7. Details, sangat memerhatikan faktor kritis secara perinci dan tidak mengabaikan hal-hal yang kecil yang dapat menghambat usahanya.

8. Destiny, ia bertanggung jawab terhadap tujuan yang hendak dicapai, serta tidak tergantung terhadap orang lain dan memiiki kebebasan.

9. Dollars, motivasinya bukan memperoleh uang dan uang dianggap sebagai ukuran kesuksesan setelah usahanya berhasil.

10. Distribute, seorang wirausaha bersedia mendistribusikan kepemilikan bisnis terhadap orang yang dapat dipercaya, kritis, dan mau diajak untuk meraih kesuksesan dalam usahanya

Pearce dalam Winardi (2003: 37) mengemukakan karakteristik wirausaha yang berhasil

(Yuyus Suryana \& Kartib Bayu, 2010), sebagai berikut:

1. Komitmen dan determinasi yang tiada batas

2. Dorongan atau rangsangan kuat untuk mencapai prestasi

3. Orientasi kearah peluang serta tujuan

4. Yakin pada diri sendiri

5. Toleransi terhadap ambiguitas

6. Mempersiapkan diri untuk mengantisipasi problem yang mungkin timbul

7. Tetap memusatkan pada peluang, pelanggan, pasar, dan persaingan

8. Tidak terintimidasi dengan situasi sulit

9. Secara agresif mencari umpan balik yang memungkinkan mempercepat kemajuan serta efektivitas

10. Kemampuan menghadapi kegagalan secara efektif dan dapat menerima kegagalan serta memanfaatkannya sebagai suatu proses belajar

Sedangkan menurut Ari Wibowo Prijosaksono (2003) (Yuyus Suryana \& Kartib Bayu, 2010) terdapat sepuluh hal yang harus dimiliki oleh seorang wirausaha, yaitu: 
1. Find your purpose and dream all the time, yaitu sukses sebuah perjalanan bukan tujuan

2. Never-ending innovation, yaitu inovasi tiada henti

3. Learn-change and grow, senantiasa belajar, belajar, dan belajar

4. Accumulative your asset tujuan akhir wirausaha adalah mencapai kebebasan finansial

5. Use leverage concept to build your business, seorang wirausaha yang cerdas harus mampu menggunakan tenaga dan waktu orang lain untuk mencapai tujuannya

6. Nurture equip develop your people, mampu menggunakan waktu dan tenaga orang lain untuk mencapai tujuannya

7. Systemize your business, mampu membangun sistem bisnis yang efektif dan efisien

8. Buikd network and alliance, mampu membuat jaringan kerja yang kuat baik dalam segi peluang bsnis, modal, maupun akses pada pemerintah

9. Be smart investor, salah satu kekuatan wirausaha yang cerdas dan sukses adalah kemampuan dalam mengelola portofolio asetnya sehinga senantiasa berkembang dan bertambah banyak

10. The power of giving: give and be grateful, kebiasaan wirausaha sejati adalah beramal dan mengucap syukur.

\section{Lingkungan Keluarga}

Keluarga merupakan unit terkecil dari masyarakat yang terdiri atas kepala keluarga dan beberapa orang yang terkumpul dan tinggal disuatu tempat dibawah suatu atap dalam keadaan saling ketergantungan. Menurut Salvicion dan Celis (1998) di dalam keluarga terdapat dua atau lebih dari dua pribadi yang tergabung karena hubungan darah, hubungan perkawinan atau pengangkatan, di hidupnya dalam satu rumah tangga, berinteraksi satu sama lain dan di dalam perannya masing-masing dan menciptakan serta mempertahankan suatu kebudayaan. Joe Kathena mengemukakan bahwa lingkungan merupakan segala sesuatu yang berada di luar individu yang meliputi fisik dan sosial budaya, lingkungan ini merupakan sumber seluruh informasi yang diterima individu melalui alat inderanya yaitu penglihatan, penciuman, pendengaran, dan rasa (Syamsu Yusuf, 2000).

Lingkungan keluarga sangat berpengaruh dalam perkembangan kepribadian seorang anak karena lingkungan keluraga adalah lingkungan primer yang kuat pengaruhnya kepada individu dibanding lingkungan sekunder (masyarakat). Pengertian lingkungan keluarga berasal dari kata lingkungan dan keluarga, menurut (Webster's New College Dictionary dalam Hadikusumo, 1996:74) pengertian lingkungan adalah kumpulan segala kondisi dan pengaruh dari luar terhadap kehidupan dan perkembangan suatu organisasi (Hadikusumo, Kunaryo, 1996). Keluarga adalah ibu bapak dengan anak-anaknya; seisi rumah yang menjadi tanggungan (Poerwadarmi nta, 1989). Dalam arti luas keluarga adalah satu persekutuan hidup yang dijalin kasih sayang antara pasangan dua jenis manusia yang dikukuhkan dengan pernikahan, yang bermaksud saling menyempurnakan diri (Soelaeman, 1994).

Keluarga merupakan kelompok sosial pertama-tama dalam kehidupan manusia tempat ia belajar dan menyatakan diri sebagai manusia sosial di dalam hubungan interaksi dengan kelompoknya. Interaksi sosial dalam keluarga berdasarkan simpati, seorang anak pertama-tama belajar memperhatikan keinginan-keinginan orang lain, belajar bekerja sama, bantu membantu, dengan kata lain anak pertama-tama belajar memegang peranan sebagai makhluk sosial yang mempunyai norma-norma dan kecakapan-kecakapan tertentu dalam pergaulannya dengan orang lain. Pekerjaan orang tua sering kali terlihat bahwa ada pengaruh dari orang tua yang bekerja sendiri dan membuka usaha sendiri maka cenderung anaknya akan menjadi pengusaha (Alma, 2009). Keadaan dimana memiliki usaha sendiri, maka hal ini dijadikan inspirasi oleh anak. Orang tua yang seperti ini cenderung akan mendukung keberanian anakanya untuk membuka usaha sendiri setelah dewasa nanti.

Orang tua atau keluarga juga merupakan peletak dasar bagi persiapaan anak-anak agar dimasa yang akan datang dapat menjadi pekerja yang efektif (Soemanto, 2008). Dalam mendidik anak, para orang tua harus mengajarkan anaknya memotivasi diri untuk bekerja keras, diberi 
kesempatan untuk bertanggung jawab atas apa yang dia lakukan. Orang tua yang berwirausaha dalam bidang tertentu dapat menimbulkan minat anaknya untuk berwirausaha dalam bidang yang sama. Memiliki seorang ibu dan ayah yang berwirausaha memberikan inspirasi kepada anaknya untuk menjadi wirausahawan. Fleksibilitas dan kemandirian dari wirausahaan telah mendarah daging pada anak sejak dini. Anak terinspirasi untuk berwirausaha karena melihat kesunggguhan dan kerja keras ayah dan ibunya atau orang tua berusaha yang menghasilkan keuntungan. Sehingga menumbuhkan minat berwirausaha didalam diri anak tersebut. Dari pengertian lingkungan dan keluarga diatas, maka dapat disimpulkan pengertian lingkungann keluarga adalah segala kondisi dan pengaruh dari luar terhadap kehidupan dan perkembangan anggota keluarga.

Lingkungan keluarga merupakan salah satu faktor lingkungan yang dapat mempengaruhi minat seseorang untuk berwirausaha. Faktor-faktor yang terkandung dalam lingkungan keluarga terdiri dari: a) Cara orang tua mendidik. Cara orang tua mendidik anaknya besar pengaruhnya terhadap cara belajar dan berfikir anak. Ada orang tua yang mendidik secara diktator militer, ada yang demokratis dan ada juga keluarga yang acuh tak acuh dengan pendapat setiap keluarga. b) Relasi antar anggota keluarga. Relasi antar anggota keluarga yang terpenting adalah relasi orang tua dengan anak-anaknya. Demi kelancaran belajar serta keberhasilan anak, perlu adanya relasi yang baik didalam keluarga. Hubungan yang baik adalah hubungan yang penuh pengertian dan kasih sayang, disertai dengan bimbingan untuk mensukseskan belajar anak. c) Suasana rumah. Suasana rumah dimaksudkan sebagai situasi atau kejadian-kejadian yang sering terjadi di dalam keluarga dimana anak berada dan belajar. Suasana rumah merupakan faktor yang penting yang tidak termasuk faktor yang disengaja. Suasana rumah yang gaduh/ramai dan semrawut tidak akan memberi ketenangan pada anak yang belajar. Suasana rumah yang tegang, ribut dan sering terjadi cekcok pertengkaran antar anggota keluarga atau dengan keluarga lain menyebabkan anak menjadi bosan di rumah, suka keluar rumah dan akibatnya belajar kacau sehingga untuk memikirkan masa depannya pun tidaklah terkonsentrasi dengan baik. d) Keadaan ekonomi keluarga Pada keluarga yang kondisi ekonominya relatif kurang, menyebabkan orang tua tidak mampu memenuhi kebutuhan pokok anak. Tak jarang faktor kesulitan ekonomi justru menjadi motivator atau pendorong anak untuk lebih berhasil. Adapun pada keluarga yang ekonominya berlebihan, orang tua cenderung mampu memenuhi segala kebutuhan anak termasuk masalah pendidikan anak termasuk bisa melanjutkan sampai ke jenjang yang tinggi. Kadangkala kondisi serba berkecukupan tersebut membuat orang tua kurang perhatian pada anak karena sudah merasa memenuhi semua kebutuhan anaknya, akibatnya anak menjadi malas untuk belajar dan prestasi yang diperoleh tidak akan baik. e) Pengertian Orang Tua. Anak belajar perlu dorongan dan pengertian dari orang tua. Kadang-kadang anak mengalami lemah semangat, maka orang tua wajib memberi pengertian dan mendorongnya, membantu sedapat mungkin kesulitan yang dialami anak baik di sekolah maupun di masyarakat. Hal ini penting untuk tetap menumbuhkan rasa percaya dirinya. f) Latar Belakang Kebudayaan. Tingkat pendidikan atau kebiasaan di dalam keluarga mempengaruhi sikap anak dalam kehidupannya (Slameto, 2010).

\section{HASIL DAN PEMBAHASAN}

Berdasarkan analisis hasil pengolahan data penelitian, maka dapat disimpulkan bahwa pengaruh lingkungan keluarga memiliki pengaruh yang signifikan terhadap minat berwirausaha peserta didik SMK di Kabupaten Subang. Adapun skor yang diperoleh yaitu 0,000 - 0,043 dimana menurut Utari Sumarmo dan Heris Hendriana (Sumarmo Utari, 2014) bahwa taraf signifikansi sebesar 5\% atau 0,05 dinyatakan valid. Skor yang diperoleh dalam uji reliabilitas pada penelitian ini sebesar 0,703 memiliki derajat keandalan yang tinggi, menurut J.P. Guildford (Suherman, 2003). 


\section{KESIMPULAN DAN SARAN}

\section{Kesimpulan}

Membangun usaha baru memberikan dampak positif bagi perkembangan sebuah bangsa. Wirausaha merupakan seseorang yang memiliki keunggulan dalam menjalankan sebuah bisnis/ usaha. Minat berwirausaha di kalangan peserta didik khususnya Sekolah Menengah Kejuruan (SMK) perlu ditingkatkan. Terdapat beberapa faktor yang berpengaruh pada peningkatan minat berwirausaha pada peserta didik SMK diantaranya faktor internal dan eksternal, namun faktor lingkungan keluarga sangat mempengaruhi minat berwirausaha peserta didik SMK di Kabupaten Subang. Jika peserta didik berada di lingkungan keluarga yang berwirausaha maka dapat memberikan dorongan pada diri peserta didik untuk dapat melanjutkan usaha keluarga maupun memberikan inspirasi pada diri peserta didik untuk membuka usaha sendiri, serta memberikan dukungan untuk memulai dan menjalankan sebuah usaha.

\section{Saran}

Penelitian ini dapat memberikan saran pada pihak lain untuk selalu mendukung dalam peningkatan minat peserta didik untuk berwirausaha, termasuk di dalamnya pihak pemangku kebijakan baik di sekolah, pemerintah, maupun Dunia Usaha/ Dunia Industri. Diharapkan selanjutnya dapat dilakukan penelitian secara empiris untuk mengetahui besarnya pengaruh lingkungan keluarga terhadap minat berwirausaha pada peserta didik khususnya peserta didik di SMK.

\section{TINJAUAN LITERATUR}

The pervasive effects of family on entrepreneurship: toward a family embeddedness perspective Howard E. Aldrich, Jennifer E. Cliff (2003)

(Aldrich \& Cliff, 2003)

Keluarga dan bisnis sering diperlakukan sebagai lembaga yang terpisah secara alami, sementara kita berdebat bahwa mereka terjalin erat. Perubahan jangka panjang dalam komposisi keluarga dan perannya. Hubungan anggota keluarga di Amerika Utara yang tumbuh lebih kecil dan kehilangan banyak hubungan. Transformasi seperti itu dalam institusi keluarga berimplikasi pada munculnya peluang bisnis baru, pengakuan peluang, keputusan memulai usaha baru, dan propses mobilisasi sumber daya. Kami menyarankan agar pakar kewirausahaan memulai usaha baru dan proses mobilisasi sumber daya. Kami menyarankan agar para pakar kewirausahaa akan mendapatkan keuntungan dari perspektif keterikatan keluarga tentang penciptaan usaha baru.

Kita membutuhkan lebih banyak penelitian tentang bagaimana sistem keluarga mempengaruhi kemunculan peluang dan pengakuan, keputusan penciptaan usaha baru, dan proses mobilisasi sumber daya. Kita perlu belajar lebih banyak lagi tentang peran yang ditunjukkan oleh karakteristik keluarga, kapan dan mengapa serta bagaimana seseorang mengidentifikasi peluang kewirausahaan dan memutuskan untuk memulai usaha bisnis yang pada gilirannya kita perlu memahami efek usaha tersebut memungkinkan pada penciptaannya ada pada sistem keluarga. Penelitian seperti itu akan dapat memperluas cakupan pendekatan sosial tertanam terhadap kewirausahaan serta membuka jalan yang lebih holistik dan lebih realistis mendekati pemahaman kita tentang fenomena wirausaha, khususnya dalam penciptaan usaha baru.

\section{The Family's Financial Support as a "Poisoned Gift": A Family Embeddedness Perspective on Entrepreneurial Intention \\ Philipp Sieger, Tommaso Minola (2016) \\ (Sieger Philipp, 2016) \\ Dukungan Keuangan Keluarga Sebagai "Hadiah Beracun": Perspektif Kelekatan \\ Keluarga Pada Wirausaha}


Kami berpendapat bahwa ketersediaan dukungan keuangan yang lebih besar oleh keluarga untuk menciptakan usaha baru, mensyaratkan kewajiban keuangan dan non-keuangan yang lebih kuat. Menyadari kewajiban ini, potensi pendiri mengantisipasi implikasi kinerja negatif untuk perusahaan yang direncanakan dan ancaman sistem keluarga dalam kasus tidak terpenuhinya kebutuhan mereka. Dengan demikian kami mendalilkan bahwa formasi aktual niat untuk berwirausaha cenderung besar dengan adanya dukungan keuangan yang tersedia. Penelitian ini mempelajari sampel 23.304 responden dari 19 negara dan menemukan hubungan negatif pada kohesi keluarga dan pada kepercayaan diri individu untuk berwirausaha.

\section{Analisis pengaruh faktor eksternal dan internal Terhadap minat berwirausaha}

Komsi Koranti 2013

Peningkatan jumlah penduduk dan terbatasnya lapangan kerja menimbulkan masalah pengangguran di Indonesia. Berbagai usaha telah dilakukan oleh Pemerintah diantaranya dengan usaha mandiri masyarakat berupa bidang kewirausahaan. Terdapat berbagai faktor yang mempengaruhi minat berwirausaha, yaitu internal dan eksternal. Analisis regresi linier berganda digunakan untuk memahami sejauh mana pengaruh faktor tersebut terhadap minat berwirausaha. Metode penelitian ini yaitu survey eksplanatory, objek penelitian ini yaitu mahasiswa Universitas Gunadarma di Depok. Jumlah sampel sebanyak 100 mahasiswa yang diambil dengan teknik sampel acak sederhana dengan menggunakan kuesioner.

Hasil penelitian diperoleh kesimpulan bahwa variabel yang paling berpengaruh terhadap minat berwirausaha yaitu motivasi, kepribadian, lingkungan kelurga dan lingkungan sekitar.

(Koranti, 2013)

\section{Pengaruh sikap, pendidikan dan lingkungan keluarga terhadap minat berwirausaha}

Ni putu pebi ardiyani, a.a.g agung artha kusuma

(Putu, Ardiyani, \& Kusuma, 2016)

Minat merupakan rasa ketertarikan terhadap objek atau aktivitas yang berasal dari kemampuan diri sendiri. Minat mendorong individu untuk melakukan kegiatan dalam suatu tujuan yang telah ditetapkan. Penelitian ini dilakukan di Fakultas Ekonomi dan Bisnis Universitas Pendidikan Ganesha dengan jumlah responden sebanyak 100 orang mahasiswa dengan menggunakan metode Slovin. Pengumpulan data yang dilakukan dengan menggunakan kuesioner. Teknik analisis yang digunakan yaitu regresi berganda. Hasil analisis menunjukkan bahwa variabel sikap, pendidikan, dan lingkungan keluarga berpengaruh positif dan signifikan terhadap minat berwirausaha.

\section{DAFTAR PUSTAKA}

Ajzen, I. (2005). Attitudes, Personality, and Behaviour.

Aldrich, H. E., \& Cliff, J. E. (2003). The pervasive effects of family on entrepreneurship : toward a family embeddedness perspective, 18, 573-596. http://doi.org/10.1016/S08839026(03)00011-9

Alma, B. (2009). Kewirausahaan. Bandung: Alfabeta.

Aprilianty, E. (2012). Pengetahuan Kewirausahaan, Dan Lingkungan the Effect of Entrepreneur Personality, Entrepreneurship Knowledge, and Environment on Entrepreneurial Interest. Pendidikan Vokasi, 2(3), 311-324. http://doi.org/10.1007/s11365-012-0246-x

Asawi, N. (2011). Wirausaha Sebagai Solusi Pengangguran Terdidik Di Indonesia. Ejournal Uin Malang, 7(no 2), 1-21. Retrieved from http://ejournal.uinmalang.ac.id/index.php/ekonomi/article/view/1754

Astamoen, I. H. M. P. (2008). Entrepreneurship dalam Perspektif Kodisi Bangsa Indonesia. Bandung: Alfabeta.

Bill, F., Bjerke, B., \& Johansson, A. W. (2010). (De)mobilizing the entrepreneurship discourse: Exploring entrepreneurial thinking and action. (De)Mobilizing the Entrepreneurship 
Discourse: Exploring Entrepreneurial Thinking and Action. Retrieved from http://www.scopus.com/inward/record.url?eid=2-s2.0-80755160103\&partnerID=tZOtx3y1

Budi Wahyono, Siswandari, D. S. (2013). Pengaruh Pendidikan Kewirausahaan Terhadap Niat Berwirausaha Siswa SMK Negeri 1 Pedan Tahun 2013, 1-17.

Burger-Helmchen, T. (2012). Entrepreneurship- Born , Made and Educated, 350. http://doi.org/10.5772/35302

Chinmay, L., Mengze, P., Chinmay, L., Mengze, P., Decision, M., Intelligence, M., ... Decision, M. (2016). Article information: Journal of Small Business and Enterprise Development, 19(3), 25. http://doi.org/10.1108/02656710210415703

$\mathrm{Fu}, \mathrm{W}$. (2016). Industrial clusters as hothouses for nascent entrepreneurs? The case of Tianhe Software Park in Guangzhou, China. The Annals of Regional Science, 57(1), 253-270. http://doi.org/10.1007/s00168-016-0776-3

Gicheva, D., \& Link, A. N. (2015). On the Economic Performance of Nascent Entrepreneurs Department of Economics Working Paper Series. Department of Economics Working Paper Series, (July).

Hadikusumo, Kunaryo, D. (1996). Pengantar Pendidikan. Semarang. Semarang: IKIP Semarang Press.

Hakim, A. (2010). Model Pengembangan Kewirausahaan Sekolah Menengah Kejuruan ( Smk ) Dalam Menciptakan Kemandirian Sekolah, 4(1), 1-14.

Kemiskinan, P., Ekonomi, P., Belanja, D. A. N., Tahun, T., \& Mirza, D. S. (2012). Economics Development Analysis Journal, 1(1), 224-234.

Koranti, K. (2013). ANALISIS PENGARUH FAKTOR EKSTERNAL DAN INTERNAL, 5(1998), 8-9.

Kusumawati, D. (2016). ANALISA PENGARUH FAKTOR INTERNAL DAN MAHASISWA SISTEM INFORMASI STMIK AKAKOM, 11-13.

Leef, N. H. (2015). Entrepreneurship Economic Development: The Problem Revisited, 17(1), $46-64$.

Lichtenstein, B. B., Carter, N. M., Dooley, K. J., \& Gartner, W. B. (2007). Complexity dynamics of nascent entrepreneurship. Journal of Business Venturing, 22(2), 236-261. http://doi.org/10.1016/j.jbusvent.2006.06.001

MacMillan, A. (2010). Be a great entrepreneur.

Mandiri, P. S., Dan, L. K., Lestari, A., Hasiolan, A. B., \& Minarsih, M. M. (2016). ( Studi Empiris di Desa Jamus Kecamatan Mranggen Kabupaten Demak ). PENGARUH SIKAP MANDIRI, LINGKUNGAN KELUARGA DAN MOTIVASI TERHADAP MINAT BERWIRAUSAHA PARA REMAJA, 2(2).

Poerwadarminta. (1989). Kamus Umum Bahasa Indonesia. Jakarta: Depdiknas.

Putu, N., Ardiyani, P., \& Kusuma, A. A. G. A. A. (2016). Pengaruh Sikap, Pendidikan dan Lingkungan Keluarga Terhadap Minat Berwirausaha, 5(8), 5155-5183.

Ramdhani, N. (2011). Penyusunan Alat Pengukur Berbasis Theory of Planned Behavior 1, 19(2), $55-69$.

Sieger Philipp, M. T. (2016). The Family â $€^{\mathrm{TM}}$ s Financial Support as a "Poisoned Gift": A Family Embeddedness Perspective on Entrepreneurial Intention The Family' s Financial Support as a " Poisoned Gift": A Family Embeddedness Perspective on Entrepreneurial Intentions, (September). http://doi.org/10.1111/jsbm.12273

Slameto. (2010). Belajar dan Faktor-Faktor yang Mempengaruhinya. Jakarta: Rineka Cipta.

Soelaeman. (1994). Pendidikan Dalam Keluarga. Bandung: Alfabeta.

Soemanto, W. (2008). Pendidikan Wirausaha. Jakarta: PT. Bumi Aksara.

Suherman, E. (2003). Penelitian Pembelajaran Matematika Kontemporer.pdf. Bandung: Universitas Pendidikan Indonesia.

Sukardi, T. (2013). Faktor-Faktor Yang Mempengaruhi Kemandirian Factors Influence the Autonomy for Entrepreneure in Student' S Smk. Jurnal Pendidikan Vokasi, 3(November), 
334-346.

Sumarmo Utari, H. H. (2014). Penilaian Pembelajaran Matematika.pdf. Bandung: Reflika Aditama.

Suryana. (2006). Kewirausahaan Pedoman Praktis : Kiat dan Proses Menuju Sukses. Jakarta: Salemba Empat.

Syamsu Yusuf. (2000). Lingkungan keluarga.

Thomson, J. D. (2006). Entrepreneurship and Innovations in E-Business. Entrepreneurship and Innovations in E-Business: An Integrative Perspective. http://doi.org/10.4018/978-1-59140920-5

Timmons, J. A., \& Spinelli, S. (n.d.). Jeffry A. Timmons and Stephen Spinelli New Venture creation Entrepreneurship for the 21, 21.

Wibowo, A. (2011). Pendidikan Kewirausahaan. Jakarta: Pustaka Pelajar.

Wisnu Septian Ginanjar Prihantoro and Hadi, S. (2016). KELUARGA TERHADAP SIKAP MENTAL. Pengaruh Pendidikan Kewirausahaan, Motivasi Berwirausaha Dan Lingkungan Keluarga Terhadap Mental Kewirausahaan, 5, 13027.

Yuyus Suryana \& Kartib Bayu. (2010). Kewirausahaan, Pendekatan Karakteristik Wirausaha Sukses. Jakarta: Kencana Prenada Media Group.

\section{Biodata Penulis}

1. Anita Wiani, merupakan mahasiswi Pendidikan Ekonomi Pascasarjana Universitas Pendidikan Indonesia, bekerja sebagai tenaga pengajar dan sebagai Ketua Kompetensi Keahlian Bisnis Daring dan Pemasaran di SMK PGRI Subang, alamat tempat tinggal di Perum Puri Subang Asri - Subang - Jawa Barat, email: anitawiani@gmail.com

2. Eeng Ahman, merupakan Dosen Pascasarjana Pendidikan Ekonomi Pascasarjana Universitas Pendidikan Indonesia, tugas lainnya selain mengajar yaitu sebagai Wakil Dekan bagian Akademik di Universitas Pendidikan Indonesia. Pendidikan formal S1 di IKIP Bandung, S2 dan S3 di Universitas Padjadjaran, di bertempat tinggal di Bandung, email: eengahman@yahoo.co.id

3. Amir Machmud merupakan Dosen Pascasarjana Pendidikan Ekonomi Universitas Pendidikan Indonesia, tugas lain selain menagajar yaitu bidang SKM Universitas Pendidikan Indonesia. Pendidikan formal S1 di Ikopin, S2 dan S3 di Universitas Padjadjaran bertempat tinggal di Bandung, email: amir@upi.edu 